\title{
Survival and Growth of Epiphytic Ferns Depend on Resource Sharing
}

\author{
Hua-Zheng $\mathrm{Lu}^{1,2^{\dagger}}$, Liang Song ${ }^{1 \dagger}$, Wen-Yao Liu ${ }^{1 *}$, Xing-Liang $\mathrm{Xu}{ }^{3}$, Yue-Hua Hu${ }^{1}$, \\ Xian-Meng Shi ${ }^{1,2}$, Su Li ${ }^{1}$, Wen-Zhang Ma ${ }^{4}$, Yan-Fen Chang ${ }^{1}$, Ze-Xin Fan ${ }^{1}$, Shu-Gang Lu ${ }^{5}$, \\ Yi Wu ${ }^{1,2}$ and Fei-Hai Yu ${ }^{6 *}$ \\ ${ }^{1}$ Key Laboratory of Tropical Forest Ecology, Xishuangbanna Tropical Botanical Garden, Chinese Academy of Sciences, \\ Mengla, China, ${ }^{2}$ University of the Chinese Academy of Sciences, Beijing, China, ${ }^{3}$ Key Laboratory of Ecosystem Network \\ Observation and Modeling, Institute of Geographic Sciences and Natural Resources Research, Chinese Academy of \\ Sciences, Beijing, China, ${ }^{4}$ Kunming Institute of Botany, Chinese Academy of Sciences, Kunming, China, ${ }^{5}$ Institute of Ecology \\ and Geobotany, Yunnan University, Kunming, China, ${ }^{6}$ School of Nature Conservation, Beijing Forestry University, Beijing, \\ China
}

\section{OPEN ACCESS}

Edited by:

Pan Kaiwen,

Chinese Academy of Sciences, China

Reviewed by:

Karl Kunert,

University of Pretoria, South Africa

Mukhtar Ahmed,

Washington State University, USA

*Correspondence:

Wen-Yao Liu

liuwy@xtbg.ac.cn

Fei-Hai Yu

feihaiyu@bjfu.edu.cn

† Joint first authors.

Specialty section

This article was submitted to Agroecology and Land Use Systems, a section of the journal Frontiers in Plant Science

Received: 04 November 2015 Accepted: 18 March 2016 Published: 31 March 2016

Citation:

LU H-Z, Song L, LiU W-Y, XU X-L,

Hu Y-H, Shi X-M, Li S, Ma W-Z, Chang Y-F, Fan Z-X, Lu S-G, Wu Y and Yu F-H (2016) Survival and Growth of Epiphytic Ferns Depend on Resource

Sharing. Front. Plant Sci. 7:416. doi: 10.3389/fp/s.2016.00416
Locally available resources can be shared within clonal plant systems through physiological integration, thus enhancing their survival and growth. Most epiphytes exhibit clonal growth habit, but few studies have tested effects of physiological integration (resource sharing) on survival and growth of epiphytes and whether such effects vary with species. We conducted two experiments, one on individuals (single ramets) and another on groups (several ramets within a plot), with severed and intact rhizome treatments (without and with physiological integration) on two dominant epiphytic ferns (Polypodiodes subamoena and Lepisorus scolopendrium) in a subtropical montane moist forest in Southwest China. Rhizome severing (preventing integration) significantly reduced ramet survival in the individual experiment and number of surviving ramets in the group experiment, and it also decreased biomass of both species in both experiments. However, the magnitude of such integration effects did not vary significantly between the two species. We conclude that resource sharing may be a general strategy for clonal epiphytes to adapt to forest canopies where resources are limited and heterogeneously distributed in space and time.

Keywords: canopy-dwelling plants, clonal growth, clonal integration, forest canopy, habitat adaptation, montane moist forest, physiological integration

\section{INTRODUCTION}

Environments are characterized by patchy distributions of abiotic and biotic factors (Alpert and Mooney, 1996; Chen et al., 2002; Jahnke et al., 2015). Clonal plants can integrate information about such environmental heterogeneity and respond accordingly (Louâpre et al., 2012; Wang et al., 2013; Oborny and Hubai, 2014; Chen et al., 2015; Saunders and Pezeshki, 2015). One strategy by which clonal plants cope with environmental heterogeneity is physiological integration, i.e., the capacity to share resources among interconnected ramets (Hutchings and Wijesinghe, 1997; Herben and Suzuki, 2001; Song et al., 2013; Roiloa et al., 2014; Dong et al., 2015). Physiological integration enables parent ramets to support offspring ramets (Matlaga and Sternberg, 2009; Oborny and Hubai, 2014; Roiloa et al., 2014; Glover et al., 2015) and ramets growing in favorable conditions to support those in unfavorable conditions (Roiloa et al., 2007; Xu L. et al., 2012; Kui et al., 2013; Tuya et al., 2013; Cornelissen et al., 2014; Luo et al., 2014). 
Forest canopies house ca. 50\% of terrestrial biodiversity (Ozanne et al., 2003; May, 2010; Lowman and Schowalter, 2012). As a key component of tropical and subtropical floras (Benzing, 2012; Zotz, 2013), canopy-dwelling epiphytes serve important ecological functions in forest hydrology and nutrient fluxes (Umana and Wanek, 2010; Zhang et al., 2015). However, epiphytic habitats are usually described as "harsh" because tree crowns are characterized by a limited storage capacity for available nutrients and water, sporadic and dilute nutrient inputs, low physical stability, extreme fluctuations in moisture and temperature, high wind speed, and severe and variable vapor pressure deficits (Théry, 2001; Zotz and Hietz, 2001; Benzing, 2012; Lowman and Schowalter, 2012). Significant variation in resource availability can occur at small spatial and temporal scales, and short-term drought can occur even in wet seasons of tropical rain forests (Zotz and Hietz, 2001; Watkins et al., 2007a). How epiphytes adapt to the harsh and heterogeneous environments of forest canopies remains one of the most fascinating questions in plant ecology (Benzing, 2012; Lowman and Schowalter, 2012; Reyes-García et al., 2012).

Almost all epiphytic bryophytes and lichens and many vascular epiphytes are capable of clonal growth (Jackson et al., 1985; During, 1990; de Kroon and van Groenendael, 1997; Benzing, 2012; Robinson and Miller, 2013). Different ramets within a clone are often interconnected via rhizomes, stolons or roots so that resource sharing (physiological integration) within the clone is possible (Eilts et al., 2011; Cornelissen et al., 2014; Weiser and Smycka, 2015). In the past decades, roles of physiological integration have been extensively documented in different species and in different habitats (Jackson et al., 1985; de Kroon and van Groenendael, 1997; Song et al., 2013). However, little is known about how physiological integration facilitates adaptation of epiphytes to forest canopies.

Recently, we selected one clonal, facultative, epiphytic fern to test effects of physiological integration in both epiphytic and terrestrial habitats in the dry season in a subtropical montane moist forest (Lu et al., 2015). We found that clonal integration contributed greatly to survival and growth of this species, and that the effect was more important in forest canopies than in forest understories ( $\mathrm{Lu}$ et al., 2015). However, the target species possesses the unique aspects of facultative epiphytes and overwintering leaves (Lu et al., 2015), and is a common yet not dominant species in the forest. Furthermore, the experiment was carried out during the dry season when seasonal drought occurred, whereas most dominant epiphytes stop growing (shed leaves) in the dry season. Thus, it is still unknown whether clonal integration also plays an important role in dominant epiphytes and during the wet season. We hypothesize that (1) physiological integration can also increase survival and growth of dominant clonal epiphytes in the wet season.

In subtropical montane moist forests in Southwest China, eight of the nine dominant vascular epiphytes are ferns (Supplementary Table 1). Seven of these ferns produce long, creeping rhizomes that may potentially be investigated in the wet season (Xu and Liu, 2005; Ma, 2009). Because epiphytic ferns vary in morphology, physiology and phenology (Schneider et al., 2004; Watkins et al., 2007b), it is likely that these epiphytic species have adapted to habitats using various strategies. We thus hypothesize that (2) clonal epiphytes with divergent traits differ in their degree of dependence on clonal integration.

To test the hypotheses, we conducted two field experiments on two dominant epiphytes with divergent traits in a wet season in a subtropical montane moist forest in Southwest China. Specifically, we addressed two questions. (1) Does clonal integration increase survival and growth of dominant epiphytes during the wet season when water stress was seemingly weak? (2) If it does, does the effect of clonal integration on survival and growth differ between the two epiphytes with divergent traits? By addressing such questions in two dominant epiphytes and in growing (wet) seasons, we aim to test whether clonal integration is a general strategy for clonal epiphytes to adapt to forest canopies. The results obtained will deepen our understanding of the strategies of epiphytes dwelling on forest canopies.

\section{MATERIALS AND METHODS}

\section{Study Site}

We conducted the two field experiments in a primary subtropical montane moist forest in the Xujiaba region $\left(24^{\circ} 32^{\prime} \mathrm{N}, 101^{\circ} 01^{\prime}\right.$ E) of Yunnan province, China, a core area covering 5100 ha of the northern crest of the Ailao Mountain National Nature Reserve. In this region, water loss occurs during the dry season, while water accumulates during the wet season (You et al., 2013a; Lu et al., 2015). During 2000-2010, the mean annual precipitation was $1874 \mathrm{~mm}$, with $87 \%$ occurring in the wet season (May to October) and $13 \%$ in the dry season (November to April), the mean annual relative humidity was $84 \%$, and the mean air temperature was $11.1^{\circ} \mathrm{C}\left(5.6^{\circ} \mathrm{C}\right.$ in January and $15.3^{\circ} \mathrm{C}$ in July; Song et al., 2012). The forest is dominated by Lithocarpus xylocarpus, Castanopsis wattii, L. chintungensis, Schima noronhae, Machilus viridis, and Hartia sinensis, and also inhabited by a diverse community of epiphytes (Li et al., 2014).

\section{Target Species}

Polypodiodes subamoena (C. B. Clarke) Ching and Lepisorus scolopendrium (Ham. ex. D. Don) Menhra are two dominant vascular epiphytes in the montane moist forest ( $\mathrm{Xu}$ and $\mathrm{Liu}$, 2005; Ma, 2009). They mainly inhabit tree bark, junctions or rocks, and are capable of clonal growth via long, creeping rhizomes with adventitious roots (Zhang, 2012). The fronds of both ferns wither in the dry season, but their rhizomes can persist for several years. These two ferns exhibit different functional traits (i.e., morphology, physiology, and growth; Table 1). P. subamoena bears remote compound fronds and pinnatipartite (15-20 paired), herbaceous laminas and mainly occurs at 2400-3300 m a.s.l., whereas L. scolopendrium bears a close single frond and a herbaceous or papery lamina and occurs at 500-2800 $\mathrm{m}$ a.s.l. (Zhang, 2012).

\section{Experiment Design Individual Experiment}

For each of the two species, we selected 60 mature ramets from the boles or crowns of 20 host trees (i.e., phorophytes) with diameter at breast height exceeding $30 \mathrm{~cm}$. Ramet height of $P$. 
TABLE 1 | Contrasting functional traits of the ramets of two species, Polypodiodes subamoena and Lepisorus scolopendrium.

\begin{tabular}{lccrr}
\hline Trait & P. subamoena & L. scolopendrium & $\boldsymbol{t}$ & $\boldsymbol{P}$ \\
\hline Frond length (cm) & $19.73 \pm 0.74$ & $16.14 \pm 0.85$ & 3.2 & $\mathbf{0 . 0 0 2}$ \\
Frond width (cm) & $4.61 \pm 0.22$ & $2.54 \pm 0.10$ & 8.7 & $<\mathbf{0 . 0 0 1}$ \\
Frond thickness (mm) & $0.33 \pm 0.02$ & $0.99 \pm 0.04$ & -14.1 & $<\mathbf{0 . 0 0 1}$ \\
Fv/Fm & $0.74 \pm 0.01$ & $0.79 \pm 0.01$ & -3.4 & $\mathbf{0 . 0 0 1}$ \\
$\begin{array}{l}\text { Aboveground mass per } \\
\text { ramet (g) }\end{array}$ & $0.24 \pm 0.02$ & $0.12 \pm 0.01$ & 5.6 & $<\mathbf{0 . 0 0 1}$ \\
$\begin{array}{l}\text { Belowground mass per } \\
\text { ramet (g) }\end{array}$ & $0.28 \pm 0.02$ & $0.25 \pm 0.02$ & 1.1 & 0.275 \\
$\begin{array}{l}\text { Total mass per ramet } \\
\text { (g) }\end{array}$ & $0.52 \pm 0.04$ & $0.37 \pm 0.02$ & 3.5 & $\mathbf{0 . 0 0 1}$ \\
$\begin{array}{l}\text { Ramet density (no. } \\
\text { dm }{ }^{-2} \text { ) }\end{array}$ & $3.40 \pm 0.11$ & $6.50 \pm 0.26$ & -11.1 & $<\mathbf{0 . 0 0 1}$ \\
& & & &
\end{tabular}

The given are mean $\pm S E$ of each species and results of $t$-tests.

Bold letters in column of " $P$ " mean significant.

subamoena was $30.0 \pm 0.4 \mathrm{~cm}$ (mean $\pm S E$, ranging from 24.0 to $33.9 \mathrm{~cm}$ ), and that of L. scolopendrium was $18.2 \pm 0.3 \mathrm{~cm}$ (mean $\pm S E$, ranging from 15.0 to $22.2 \mathrm{~cm}$ ). Half of the ramets were randomly assigned to the severed-rhizome treatment and the other half to the intact-rhizome treatment. For the severed treatment, the rhizome internodes at both ends of the ramet were carefully exposed and cut off halfway from the ramet to prevent clonal integration. For the intact treatment, the rhizome internodes of the ramet were also carefully exposed, but no cutting was conducted so that physiological integration was allowed. The experiment started on July 26, 2013 and ended on October 26, 2013. At the end of the experiment, the survival status of all ramets was noted and the surviving ramets were harvested. A ramet was considered dead if all its fronds were shed, dried or withered. We measured frond length and width of the ramets with a ruler and frond thickness with calipers. Biomass was measured after drying the ramets at $70^{\circ} \mathrm{C}$ for $48 \mathrm{~h}$. One day before harvest, we also measured maximum quantum yield of PS II $\left(\mathrm{F}_{\mathrm{v}} / \mathrm{F}_{\mathrm{m}}\right)$ using a portable fluorometer (FSM-2; Hansatech, Norfolk, UK).

\section{Group Experiment}

For each species, we selected 20 plots, each with at least three ramets of the target species. Plots were located on 20 phorophytes (with diameter at breast height $>30 \mathrm{~cm}$ ). Half of the plots were randomly selected and subjected to the severed-rhizome treatment, and the remaining half to the intactrhizome treatment. For the severed treatment, the rhizomes along the edges of each plot were carefully exposed by removing surrounding soil, humus, mosses and/or lichens, if any, and cut off with a sharp blade so that ramets inside the plot were disconnected from those outside the plot to prevent integration. For the intact treatment, the rhizomes along the edges of each plot were also carefully exposed, but were kept intact (i.e., not cut off) so that ramets inside the plot were connected with those outside to allow integration. The experiment started on July 30, 2013 and ended on October 30, 2013. At harvest, we counted number of surviving ramets and measured length, width, and thickness of the fronds of each surviving ramet in each plot. One day before harvest, we measured $\mathrm{F}_{\mathrm{v}} / \mathrm{F}_{\mathrm{m}}$ using the FMS2 on the fronds of two ramets in each plot. Biomass in each plot was measured after drying the plant materials at $70^{\circ} \mathrm{C}$ for $48 \mathrm{~h}$.

\section{Statistical Analyses}

We analyzed the data from the two experiments separately. For the individual experiment, we used logistic regression to test the effect of rhizome severing (intact vs. severed) on survival of the ramets because the data of survival were binary (alive or dead) (McCullagh and Nelder, 1989). We used two-way ANOVA to test the effects of rhizome severing, species, and their interaction on growth (total biomass, aboveground, and belowground biomass), morphology (frond length, width and thickness), and physiology $\left(\mathrm{F}_{\mathrm{v}} / \mathrm{F}_{\mathrm{m}}\right)$ of the individual ramets.

For the group experiment, we expressed the final biomass data on a per initial ramet basis because initial number of ramets differed greatly between the two species [P. subamoena vs. L. scolopendrium: $3.4 \pm 0.11$ vs. $6.5 \pm 0.26 \mathrm{~g}$ (mean $\pm \mathrm{SE}$ ); $t=-11.07, P<0.001, n=40]$. We also calculated mean frond length, width and thickness and $\mathrm{F}_{\mathrm{v}} / \mathrm{F}_{\mathrm{m}}$ of the ramets in each plot. We then used two-way ANOVA to test the effects of rhizome severing, species and their interactions on number of surviving ramets, growth, morphology and physiology in the group experiment. When needed, data were transformed to square root or natural logarithm to meet the ANOVA assumptions. Statistical analyses were carried out with SPSS 19.0 (IBM, Armonk, NY, USA) and R software (R Development Core Team, 2012).

\section{RESULTS}

\section{Individual Experiment}

In the individual experiment, rhizome severing significantly affected survival of the single ramets $\left(\chi^{2}=8.61, P=0.003\right)$, and such effects were not species-dependent (i.e., no interaction effect; $\chi^{2}=0.02, P=0.893$ ). Survival rates of the single ramets were $86.7 \%$ for P. subamoena and $83.3 \%$ for L. scolopendrium when the rhizomes were intact, but were reduced to 63.3 and $60.0 \%$ when the rhizomes were severed (Figure 1A).

Rhizome severing significantly decreased total and belowground biomass (Table 2; Figure 1B) and maximum quantum yield of PS II ( $\mathrm{F}_{\mathrm{v}} / \mathrm{F}_{\mathrm{m}}$; Table 2; Figure $\left.\mathrm{C}\right)$ of the single ramets of both epiphytes. Such effects did not depend on species (no Se $\times$ Sp interaction; Table 2). Severing had no effect on frond length, width or thickness of the single ramets of either species (Figures 1D-F). Species significantly affected biomass, $\mathrm{F}_{\mathrm{v}} / \mathrm{F}_{\mathrm{m}}$, frond length, width and thickness (Table 2; Figure 1), affirming the contrasting growth, physiological and morphological traits of these two species (Table 1).

\section{Group Experiment}

In the group experiment, rhizome severing significantly reduced number of ramets, total biomass and belowground biomass of both epiphytes, and such effects did not depend on species (no Se $\times$ Sp interaction; Table 3; Figures 2A,B). Rhizome 

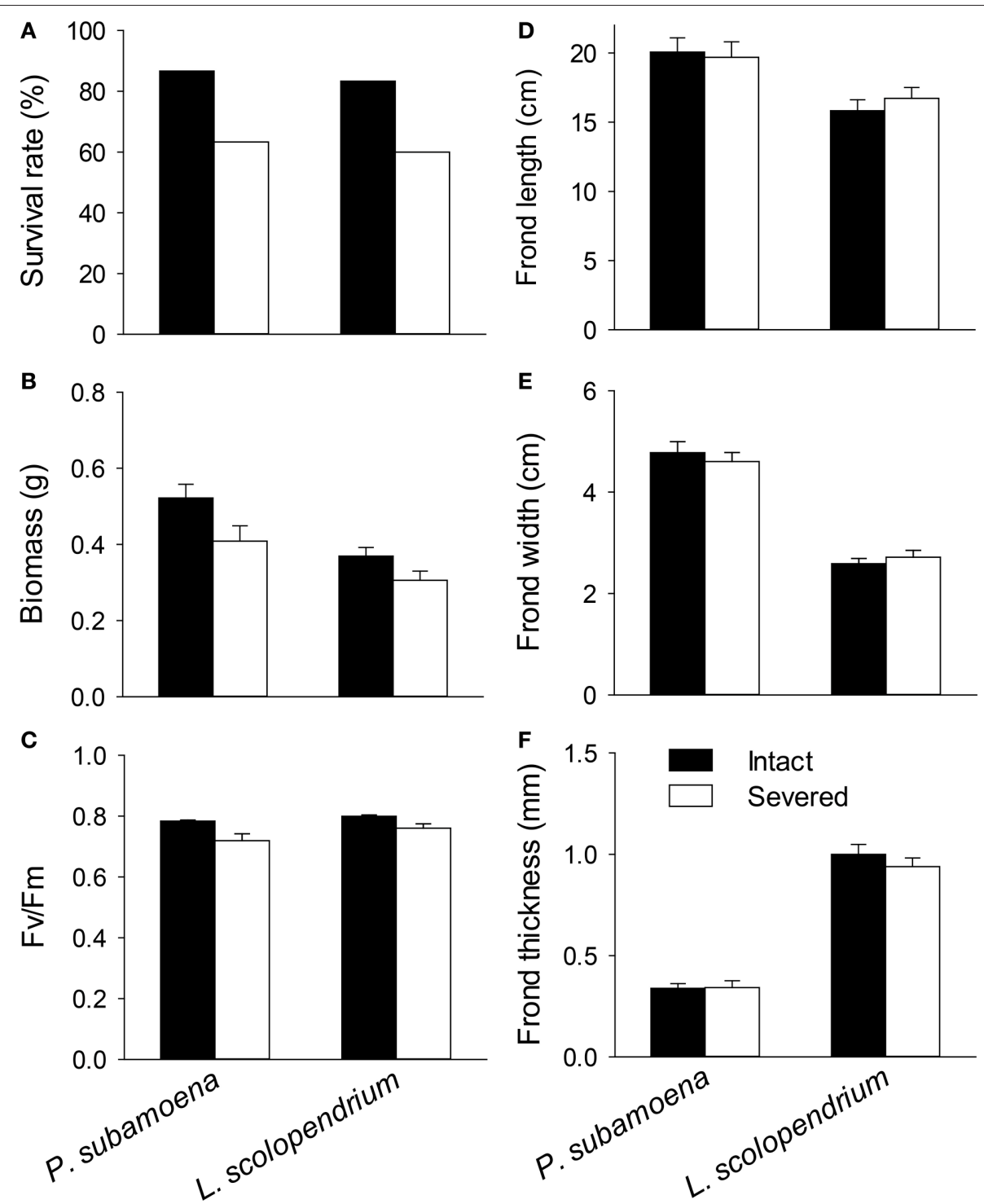

FIGURE 1 | Effects of rhizome severing on (A) survival, (B) biomass, (C) $F_{v} / F_{m}$, and (D-F) frond morphology of the two epiphytic ferns in the individual experiment. Error bars represent SEs.

severing did not significantly affect $\mathrm{F}_{\mathrm{v}} / \mathrm{F}_{\mathrm{m}}$, frond length, width or thickness of either species (Table 3; Figures 2C-F). Species significantly affected aboveground and belowground biomass, $\mathrm{F}_{\mathrm{v}} / \mathrm{F}_{\mathrm{m}}$, frond length, width and thickness (Table 3; Figure 2).

\section{DISCUSSION}

Both individual and group experiments showed that severing rhizomes decreased survival and growth of the two dominant epiphytic ferns in the wet season, supporting the first hypothesis that clonal integration (resource sharing) contributes to performance of epiphytes. These results agree with the findings on the facultative epiphytic fern Selliguea griffithiana (i.e., growing in both epiphytic and terrestrial habitats) conducted in a dry season in the same forest using similar approaches ( $\mathrm{Lu}$ et al., 2015) and also those on the terrestrial fern Diplopterygium glaucum in a subtropical evergreen forest in China (Du et al., 2010). While numerous studies have tested effects of clonal integration (Song et al., 2013; Glover et al., 2015; Weiser and Smycka, 2015), very few have examined those on performance of epiphytes (Lu et al., 2015). This study of multiple species verified the key role of resource sharing for epiphytes in surviving and growing in the wet season.

Extraordinary heterogeneity is present because light intensity and temperature diminish downward through the forest canopy, whereas humidity and nutrients increase toward the ground (Benzing, 2012). Epiphytes also suffer from water shortage between rainfall events even in wet seasons in tropical forests 
(Watkins et al., 2007a; Bartels and Chen, 2012). Our study site is characterized by a seasonal climate with variation in precipitation (You et al., 2013a). Although the forest is exposed to frequent

TABLE 2 | Individual experiment results of a two-way ANOVA for effects of species and rhizome severing on biomass, $F_{v} / F_{m}$, and frond morphology.

\begin{tabular}{|c|c|c|c|}
\hline Trait & Species (Sp) & Severing (Se) & Se $\times S p$ \\
\hline Total mass ${ }^{a}$ & $13.18^{\star \star \star}$ & $8.68^{\star \star}$ & 0.17 \\
\hline Aboveground mass ${ }^{a}$ & $64.01^{\star \star *}$ & 0.74 & 0.58 \\
\hline Belowground mass & 0.01 & $12.65^{\star *}$ & 2.06 \\
\hline $\mathrm{F}_{\mathrm{v}} / \mathrm{F}_{\mathrm{m}}^{\mathrm{a}}$ & $5.47^{\star}$ & $17.84^{\star * \star}$ & 1.05 \\
\hline Frond length & $15.288^{\star \star *}$ & 0.08 & 0.48 \\
\hline Frond widtha & $141.98^{\star \star *}$ & 0.03 & 0.61 \\
\hline Frond thickness & $251.74^{\star \star \star}$ & 0.53 & 0.67 \\
\hline
\end{tabular}

F statistics are shown with significance levels $\left({ }^{\star \star \star} P<0.001\right.$; $\left.{ }^{\star \star} P<0.01 ;{ }^{\star} P<0.05\right)$.

${ }^{a}$ Analysis performed on square-root transformed data. rain and mist during the wet season, alternating wet and dry events occur daily and weekly (You et al., 2013a,b). Large trees have great microhabitat heterogeneity within their crowns and exhibit substantial changes from the inner to the outer crown in branch diameter, canopy humus cover, openness, and mean daily maximum vapor pressure deficits (Woods et al., 2015). Epiphytes dwelling in these large treetops must cope with microhabitat heterogeneity (Théry, 2001; Zotz and Hietz, 2001; Benzing, 2012). The findings of this study and the previous one ( $\mathrm{Lu}$ et al., 2015) suggest that clonal epiphytes may evolve a high degree of clonal integration to alleviate resource stress in both wet and dry seasons. This may especially be the case for epiphytic ferns that exhibit poor water conservation owing to their limited hydraulic conductance and passive stomatal control (McAdam and Brodribb, 2012a,b).

Effects of clonal integration may differ among species (Song et al., 2013; Isogimi et al., 2014) and even among genotypes of the same species (Alpert et al., 2003; D'Hertefeldt et al.,

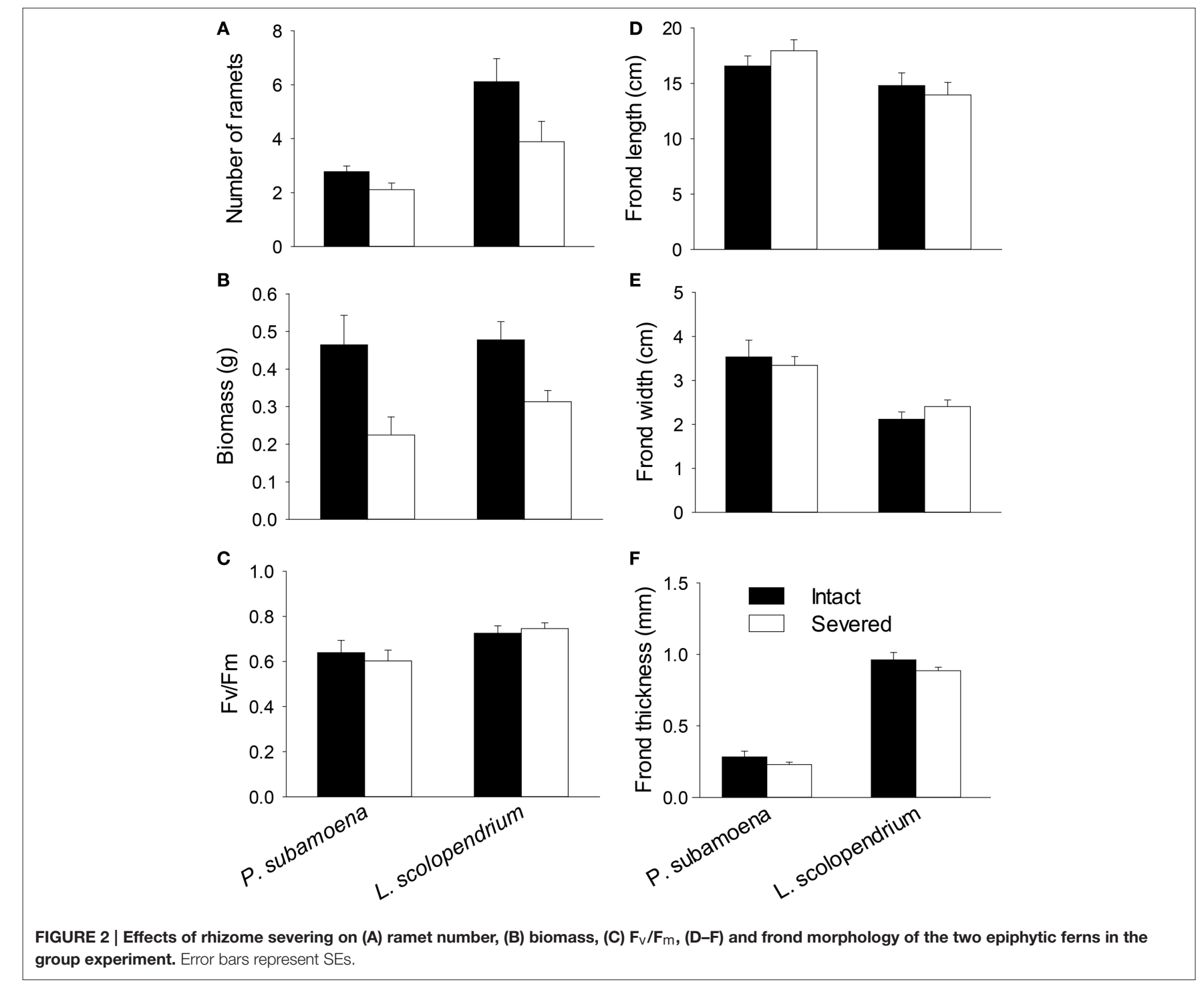


TABLE 3 | Group experiment results of a two-way ANOVA for effects of species and rhizome severing on the number of ramets, biomass, $F_{v} / F_{m}$, and frond morphology.

\begin{tabular}{|c|c|c|c|}
\hline Trait & Species (Sp) & Severing (Se) & Se $\times \mathrm{Sp}$ \\
\hline Number of ramets ${ }^{a}$ & 0.72 & $6.36^{*}$ & 1.73 \\
\hline Total mass & 0.88 & $13.99^{\star \star}$ & 0.49 \\
\hline Aboveground mass & $11.45^{\star \star}$ & 2.39 & 1.55 \\
\hline Belowground mass ${ }^{b}$ & $4.77^{*}$ & $12.75^{\star \star}$ & 0.12 \\
\hline $\mathrm{F}_{\mathrm{v}} / \mathrm{F}_{\mathrm{m}}^{\mathrm{b}}$ & $6.78^{\star}$ & 0.04 & 0.43 \\
\hline Frond length & $4.51^{*}$ & 0.04 & 0.67 \\
\hline Frond width & $20.86^{\star \star \star}$ & 0.03 & 0.87 \\
\hline Frond thickness ${ }^{b}$ & $308.86^{\star \star *}$ & 2.89 & 0.08 \\
\hline
\end{tabular}

F statistics are shown with significance levels $\left.{ }^{\star \star \star \star} P<0.001 ;{ }^{* \star} P<0.01 ;{ }^{\star} P<0.05\right)$.

a Analysis performed on log transformed data.

${ }^{b}$ Analysis performed on square-root transformed data.

2014; Zhou et al., 2014). For instance, rhizomatous species may be more reliant on clonal integration than stoloniferous species (Song et al., 2013), and genotypes from sand dunes have shown a greater impact of clonal integration than those from grasslands (Alpert, 1999). Although, the two epiphytic ferns differ greatly in morphological, physiological, and growth traits (Tables 1-3, Figures 1, 2), we found that the effects of clonal integration on ramet survival or growth did not differ significantly between the two epiphytes. These results thus do not support the second hypothesis, and suggest that clonal integration may be a general strategy for clonal epiphytes to survive and grow in forest canopies where resources are rather limited and also heterogeneously distributed in space and in time.

Clonal integration had a significant effect on $\mathrm{F}_{\mathrm{v}} / \mathrm{F}_{\mathrm{m}}$ of epiphytes in the individual experiment, but not in the group experiment (Tables 2, 3, Figures 1, 2). Previous studies also showed contrasting effects of clonal integration on photochemical activity of ramets (Luo et al., 2014; Roiloa et al., 2014). For instance, integration significantly affected photochemical activity of Alternanthera philoxeroides (Luo et al., 2014) and Fragaria vesca (Roiloa et al., 2014), but had little effect on that of the terrestrial fern D. glaucum (Du et al., 2010). Thus, effects of clonal integration on photochemical activity of the fronds may not be translated into the effects on survival and growth of the ramets. Data on survival and growth are more robust to evaluate the benefits of clonal integration.

We observed little impact of clonal integration on frond morphology of either of the epiphytes in either of the experiments (Tables 2, 3, Figures 1, 2), agreeing with the findings of our previous study (Lu et al., 2015). However, many studies have shown a significant effect of clonal integration on morphological traits such as length and thickness of petioles and internodes of stolons and rhizomes (Alpert, 1999; Saitoh et al., 2002; Xu C. et al., 2012; Dong et al., 2015; Glover et al., 2015). Our results suggest that clonal epiphytes may not rely on integration-mediated changes in frond morphology to adapt to forest canopies.

\section{CONCLUSIONS}

Our results indicate that clonal integration (resource sharing) may have been selected for as a general trait for clonal epiphytes to adapt to the harsh and heterogeneous epiphytic habitats. While epiphytes have been shown to take different strategies to adapt to forest canopies (Benzing, 2012; Lowman and Schowalter, 2012; Reyes-García et al., 2012), our study suggests that resource sharing is an additional one for clonal epiphytes. Epiphytes are a key component of forest canopies and play important roles in maintaining biodiversity (e.g., fauna diversity; Ozanne et al., 2003; Ellwood and Foster, 2004; May, 2010) and ecosystem functioning (e.g., carbon and nutrient cycling; Umana and Wanek, 2010; Benzing, 2012; Lowman and Schowalter, 2012). Considering that many epiphytes are clonal and also most of the dominant epiphytes are clonal (Jackson et al., 1985; During, 1990; de Kroon and van Groenendael, 1997; Benzing, 2012; Robinson and Miller, 2013), we hypothesize further that resource sharing may also play important roles during the underlying processes by promoting survival and growth of clonal epiphytes. Therefore, further studies could be designed to examine whether effects of resource sharing within clones of epiphytes can be cascaded to affect biodiversity and ecosystem functioning.

\section{AUTHOR CONTRIBUTIONS}

WL and FY designed the project. HL, LS, and FY performed the experiments, analyzed the data and wrote the manuscript text. XX, YH, SL, ZF, and SGL analyzed some data and prepared some figures and tables. XS, WM, YC, and YW did some field work and collected data. All authors reviewed the manuscript.

\section{ACKNOWLEDGMENTS}

We thank Mr. Yuanxiang Lu, Wenzheng Yang, and Dawen Li for help with field work, Ailaoshan Station for Subtropical Forest Ecosystem Studies and Central Laboratory of XTBG for providing background data and equipment, and two reviewers for their valuable comments. This study was supported by NSFC (31300459, U1133605, and 31300382), the Yunnan Natural Science Foundation (2013FB076), and the CAS135 Program (XTBG-F01). FY acknowledges the Open Fund from Key Laboratory of Tropical Forest Ecology, Xishuangbanna Tropical Botanical Garden, Chinese Academy of Sciences.

\section{SUPPLEMENTARY MATERIAL}

The Supplementary Material for this article can be found online at: http://journal.frontiersin.org/article/10.3389/fpls.2016. 00416 


\section{REFERENCES}

Alpert, P., Holzapfel, C., and Slominski, C. (2003). Differences in performance between genotypes of Fragaria chiloensis with different degrees of resource sharing. J. Ecol. 91, 27-35. doi: 10.1046/j.1365-2745.2003.00737.x

Alpert, P., and Mooney, H. A. (1996). Resource heterogeneity generated by shrubs and topography on coastal sand dunes. Vegetatio 122, 83-93. doi: 10.1007/BF00052818

Alpert, P. (1999). Clonal integration in Fragaria chiloensis differs between populations: ramets from grassland are selfish. Oecologia 120, 69-76. doi: 10.1007/s004420050834

Bartels, S. F., and Chen, H. Y. H. (2012). Mechanisms regulating epiphytic plant diversity. Crit. Rev. Plant Sci. 31, 391-400. doi: 10.1080/07352689.2012.680349

Benzing, D. H. (2012). Air Plants: Epiphytes and Aerial Gardens. New York, NY: Cornell University Press.

Chen, B. J. W., Vermeulen, P. J., During, H. J., and Anten, N. P. R. (2015). Testing for disconnection and distance effects on physiological self-recognition within clonal fragments of Potentilla reptans. Front. Plant Sci. 6:215. doi: 10.3389/fpls.2015.00215

Chen, Y., Yu, F., and Dong, M. (2002). Scale-dependent spatial heterogeneity of vegetation in Mu Us sandy land, a semi-arid area of China. Plant Ecol. 162, 135-142. doi: 10.1023/A:1020318509972

Cornelissen, J. H. C., Song, Y., Yu, F., and Dong, M. (2014). Plant traits and ecosystem effects of clonality: a new research agenda. Ann. Bot. 114, 369-376. doi: $10.1093 / \mathrm{aob} / \mathrm{mcu} 113$

de Kroon, H., and van Groenendael, J. (1997). The Ecology and Evolution of Clonal Plants. Leiden: Backhuys Publishers.

D'Hertefeldt, T., Eneström, J. M., and Pettersson, L. B. (2014). Geographic and habitat origin influence biomass production and storage translocation in the clonal plant Aegopodium podagraria. PLoS ONE 9:e85407. doi: 10.1371/journal.pone.0085407

Dong, B., Alpert, P., Zhang, Q., and Yu, F. (2015). Clonal integration in homogeneous environments increases performance of Alternanthera philoxeroides. Oecologia 179, 393-403. doi: 10.1007/s00442-015-3338-y

Du, J., Wang, N., Alpert, P., Yu, M., Yu, F., and Dong, M. (2010). Clonal integration increases performance of ramets of the fern Diplopterygium glaucum in an evergreen forest in southeastern China. Flora 205, 399-403. doi: 10.1016/j.flora.2009.12.018

During, H. J. (1990). "Clonal growth patterns among bryophytes", in Clonal Growth in Plants: Regulation and Function, eds J. van Groenendael and H. de Kroon (The Hague: SPB Academic Publishing), 153-176.

Eilts, J. A., Mittelbach, G. G., Reynolds, H. L., and Gross, K. L. (2011). Resource heterogeneity, soil fertility, and species diversity: effects of clonal species on plant communities. Am. Nat. 177, 574-588. doi: 10.1086/659633

Ellwood, M. D., and Foster, W. A. (2004). Doubling the estimate of invertebrate biomass in a rainforest canopy. Nature 429, 549-551. doi: 10.1038/nature02560

Glover, R., Drenovsky, R. E., Futrell, C. J., and Grewell, B. J. (2015). Clonal integration in Ludwigia hexapetala under different light regimes. Aquat. Bot. 122, 40-46. doi: 10.1016/j.aquabot.2015.01.004

Herben, T., and Suzuki, J. I. (2001). A simulation study of the effects of architectural constraints and resource translocation on population structure and competition in clonal plants. Evol Ecol. 15, 403-423. doi: 10.1023/A:1016045200996

Hutchings, M. J., and Wijesinghe, D. K. (1997). Patchy habitats, division of labour and growth dividends in clonal plants. Trends Ecol. Evol. 12, 390-394. doi: 10.1016/S0169-5347(97)87382-X

Isogimi, T., Matsushita, M., and Nakagawa, M. (2014). Species-specific sprouting pattern in two dioecious Lindera shrubs: the role of physiological integration. Flora 209, 718-724. doi: 10.1016/j.flora.2014.08.006

Jackson, J. B. C., Buss, L. W., and Cook, R. E. (1985). Population Biology and Evolution of Clonal Organisms. New Haven, CT: Yale University Press.

Jahnke, M., Pages, J. F., Alcoverro, T., Lavery, P. S., McMahon, K. M., and Procaccini, G. (2015). Should we sync? Seascape-level genetic and ecological factors determine seagrass flowering patterns. J. Ecol. 103, 1464-1474. doi: $10.1111 / 1365-2745.12470$

Kui, L., Li, F., Moore, G., and West, J. (2013). Can the riparian invader, Arundo donax, benefit from clonal integration? Weed Res. 53, 370-377. doi: $10.1111 /$ wre. 12036
Li, S., Liu, W., Li, D., Li, Z., Song, L., Chen, K., et al. (2014). Slower rates of litter decomposition of dominant epiphytes in the canopy than on the forest floor in a subtropical montane forest, southwest China. Soil Biol. Biochem. 70, 211-220. doi: 10.1016/j.soilbio.2013.12.031

Louâpre, P., Bittebière, A., Clément, B., Pierre, J., and Mony, C. (2012). How past and present influence the foraging of clonal plants? PLOS ONE 7:e38288. doi: 10.1371/journal.pone.0038288

Lowman, M. D., and Schowalter, T. D. (2012). Plant science in forest canopies: the first 30 years of advances and challenges (1980-2010). New Phytol. 194, 12-27. doi: 10.1111/j.1469-8137.2012.04076.x

Lu, H., Liu, W., Yu, F., Song, L., Xu, X., Wu, C., et al. (2015). Higher clonal integration in the facultative epiphytic fern Selliguea griffithiana growing in the forest canopy compared with the forest understorey. Ann. Bot. 116, 113-122. doi: 10.1093/aob/mcv059

Luo, F., Chen, Y., Huang, L., Wang, A., Zhang, M., and Yu, F. (2014). Shifting effects of physiological integration on performance of a clonal plant during submergence and de-submergence. Ann. Bot. 113, 1265-1274. doi: $10.1093 / \mathrm{aob} / \mathrm{mcu} 057$

Ma, W. (2009). The Composition and Biomass of Epiphytic Materials and their Relationships with Ecological factors in Xujiaba Region from Ailao Mountain, Yunnan. Ph.D. thesis, Tropical Botanical Garden, Chinese Academy of Sciences, Xishuangbanna.

Matlaga, D. P., and Sternberg, L. S. L. (2009). Ephemeral clonal integration in Calathea marantifolia (Marantaceae): evidence of diminished integration over time. Am. J. Bot. 96, 431-438. doi: 10.3732/ajb.0800164

May, R. M. (2010). Tropical arthropod species, more or less? Science 329, 41-42. doi: $10.1126 /$ science.1191058

McAdam, S. A. M., and Brodribb, T. J. (2012a). Fern and lycophyte guard cells do not respond to endogenous abscisic acid. Plant Cell 24, 1510-1521. doi: $10.1105 /$ tpc.112.096404

McAdam, S. A. M., and Brodribb, T. J. (2012b). Stomatal innovation and the rise of seed plants. Ecol. Lett. 15, 1-8. doi: 10.1111/j.1461-0248.2011.01700.x

McCullagh, P., and Nelder, J. A. (1989). Generalized Linear Models, 2nd Edn. London: Chapman and Hall.

Oborny, B., and Hubai, A. G. (2014). Patch size and distance: modelling habitat structure from the perspective of clonal growth. Ann. Bot. 114, 389-398. doi: $10.1093 / \mathrm{aob} / \mathrm{mcu} 110$

Ozanne, C. M. P., Anhuf, D., Boulter, S. L., Keller, M., Kitching, R. L., Körner, C., et al. (2003). Biodiversity meets the atmosphere: a global view of forest canopies. Science 301, 183-186. doi: 10.1126/science.1084507

R Development Core Team (2012). R: A Language and Environment for Statistical Computing. Vienna: R Foundation for Statistical Computing. Available online at: http://www.R-project.org

Reyes-García, C., Mejia-Chang, M., and Griffiths, H. (2012). High but not dry: diverse epiphytic bromeliad adaptations to exposure within a seasonally dry tropical forest community. New Phytol. 193, 745-754. doi: 10.1111/j.14698137.2011.03946.x

Robinson, S. C., and Miller, N. G. (2013). Bryophyte diversity on Adirondack alpine summits is maintained by dissemination and establishment of vegetative fragments and spores. Bryologist 116, 382-391. doi: 10.1639/0007-2745116.4.382

Roiloa, S. R., Alpert, P., Tharayil, N., Hancock, G., and Bhowmik, P. C. (2007). Greater capacity for division of labour in clones of Fragaria chiloensis from patchier habitats. J. Ecol. 95, 397-405. doi: 10.1111/j.1365-2745.2007.01216.x

Roiloa, S. R., Antelo, B., and Retuerto, R. (2014). Physiological integration modifies delta $\mathrm{N}^{15}$ in the clonal plant Fragaria vesca, suggesting preferential transport of nitrogen to water-stressed offspring. Ann. Bot. 114, 399-411. doi: 10.1093/aob/mcu064

Saitoh, T., Seiwa, K., and Nishiwaki, A. (2002). Importance of physiological integration of dwarf bamboo to persistence in forest understorey: a field experiment. J. Ecol. 90, 78-85. doi: 10.1046/j.0022-0477.2001.00631.x

Saunders, L. E., and Pezeshki, R. (2015). Morphological differences in response to physiological integration and spatial heterogeneity of root zone glyphosate exposure in connected ramets of Ludwigia peploides (Creeping water primrose). Water Air Soil Pollut. 226, 171. doi: 10.1007/s11270-015-2435-1

Schneider, H., Schuettpelz, E., Pryer, K. M., Cranfill, R., Magallón, S., and Lupia, R. (2004). Ferns diversified in the shadow of angiosperms. Nature. 428, 553-557. doi: $10.1038 /$ nature 02361 
Song, L., Liu, W., and Nadkarni, N. M. (2012). Response of non-vascular epiphytes to simulated climate change in a montane moist evergreen broad-leaved forest in southwest China. Biol. Conserv. 152, 127-135. doi: 10.1016/j.biocon.2012.04.002

Song, Y., Yu, F., Keser, L. H., Dawson, W., Fischer, M., Dong, M., et al. (2013). United we stand, divided we fall: a meta-analysis of experiments on clonal integration and its relationship to invasiveness. Oecologia 171, 317-327. doi: 10.1007/s00442-012-2430-9

Théry, M. (2001). Forest light and its influence on habitat selection. Plant Ecol. 153, 251-261. doi: 10.1023/A:1017592631542

Tuya, F., Espino, F., and Terrados, J. (2013). Preservation of seagrass clonal integration buffers against burial stress. J. Exp. Mar. Biol. Ecol. 439, 42-46. doi: 10.1016/j.jembe.2012.10.015

Umana, N. H., and Wanek, W. (2010). Large canopy exchange fluxes of inorganic and organic nitrogen and preferential retention of nitrogen by epiphytes in a tropical lowland rainforest. Ecosystems 13, 367-381. doi: 10.1007/s10021-0109324-7

Wang, Z., van Kleunen, M., During, H. J., and Werger, M. J. A. (2013). Root foraging increases performance of the clonal plant Potentilla reptans in heterogeneous nutrient environments. PLoS ONE 8:e58602. doi: 10.1371/journal.pone.0058602

Watkins, J. E. Jr., Mack, M. C., Sinclair, T. R., and Mulkey, S. S. (2007a). Ecological and evolutionary consequences of desiccation tolerance in tropical fern gametophytes. New Phytol. 176, 708-717. doi: 10.1111/j.14698137.2007.02194.x

Watkins, J. E. Jr., Rundel, P. W., and Cardelús, C. L. (2007b). The influence of life form on carbon and nitrogen relationships in tropical rainforest ferns. Oecologia 153, 225-232. doi: 10.1007/s00442-007-0723-1

Weiser, M., and Smycka, J. (2015). A simple model for the influence of habitat resource availability on lateral clonal spread. Proc. R. Soc. B Biol. Sci. 282:20150327. doi: 10.1098/rspb.2015.0327

Woods, C. L., Cardelus, C. L., and DeWalt, S. J. (2015). Microhabitat associations of vascular epiphytes in a wet tropical forest canopy. J. Ecol. 103, 421-430. doi: 10.1111/1365-2745.12357

Xu, C., Schooler, S. S., and Van Klinken, R. D. (2012). Differential influence of clonal integration on morphological and growth responses to light in two invasive herbs. PLOS ONE 7:e35873. doi: 10.1371/journal.pone.00 35873
$\mathrm{Xu}, \mathrm{H}$., and Liu, W. (2005). Species diversity and distribution of epiphytes in the montane moist evergreen broad-leaved forest in Ailao Mountain, Yunnan. Biodiv. Sci. 13, 137-147. doi: 10.1360/biodiv.040123

Xu, L., Yu, F., van Drunen, E., Schieving, F., Dong, M., and Anten, N. P. (2012). Trampling, defoliation and physiological integration affect growth, morphological and mechanical properties of a root-suckering clonal tree. Ann. Bot. 109, 1001-1008. doi: 10.1093/aob/mcs006

You, G., Zhang, Y., Liu, Y., Schaefer, D., Gong, H., Gao, J., et al. (2013a). Investigation of temperature and aridity at different elevations of Mt. Ailao, SW China. Int. J. Biometeorol. 57, 487-492. doi: 10.1007/s00484-012-0570-6

You, G., Zhang, Y., Liu, Y., Song, Q., Lu, Z., Tan, Z., et al. (2013b). On the attribution of changing pan evaporation in a nature reserve in SW China. Hydrol. Process. 27, 2676-2682. doi: 10.1002/hyp.9394

Zhang, S., Dai, Y., Hao, G., Li, J., Fu, X., and Zhang, J. (2015). Differentiation of water-related traits in terrestrial and epiphytic Cymbidium species. Front. Plant Sci. 6:260. doi: 10.3389/fpls.2015.00260

Zhang, X. (2012). Lycopods and Ferns of China. Beijing: Peking University Press.

Zhou, C., Zhang, Z., Wang, Z., and Yang, Y. (2014). Difference in capacity of physiological integration between two ecotypes of Leymus chinensis underlies their different performance. Plant Soil 383, 191-202. doi: 10.1007/s11104-0142169-7

Zotz, G., and Hietz, P. (2001). The physiological ecology of vascular epiphytes: current knowledge, open questions. J. Exp. Bot. 52, 2067-2078. doi: $10.1093 /$ jexbot/52.364.2067

Zotz, G. (2013). The systematic distribution of vascular epiphytes: a critical update. Bot. J. Linn. Soc. 171, 453-481. doi: 10.1111/boj.12010

Conflict of Interest Statement: The authors declare that the research was conducted in the absence of any commercial or financial relationships that could be construed as a potential conflict of interest.

Copyright (C) $2016 \mathrm{Lu}$, Song, Liu, Xu, Hu, Shi, Li, Ma, Chang, Fan, Lu, Wu and Yu. This is an open-access article distributed under the terms of the Creative Commons Attribution License (CC BY). The use, distribution or reproduction in other forums is permitted, provided the original author(s) or licensor are credited and that the original publication in this journal is cited, in accordance with accepted academic practice. No use, distribution or reproduction is permitted which does not comply with these terms. 